\title{
Relationships between Attitudes toward Air-Conditioning, Energy Conservation Behaviors, and Implementation of Measures against Heatstroke/Heat Shock
}

\author{
Ryo MukaE ${ }^{1^{\dagger}}{ }^{\dagger}$, Mariko Kino ${ }^{1}$, Kazuyuki Kobayashi ${ }^{2}$, and Daiki SAKAmoto ${ }^{2}$ \\ (Received March 12, 2019)
}

\section{冷暖房への態度及び省エネルギー行動と熱中症・ヒートショック対策の実施との関連 \\ 向江 亮 $* 1 \dagger$, 木方真理子 $* 1$, 小林和幸 $* 2$, 坂本大樹 $* 2$}

The objective of this study was to investigate whether attitudes toward energy utilization such as airconditioning (cooling and heating) and energy conservation behaviors are related to recognition of health risk of heatstroke/heat shock and implementation of measures against them. In this study, we conducted a secondary analysis of 3,066 respondents who answered the questionnaire survey on lifestyles of inhabitants in the former TEPCO supply area implemented in February 2018. As the results of logistic regression analysis, it was shown that house construction year, attitudes towards health, attitudes towards cooling and heating, and energy conservation behavior had relationships with recognition of health risk of heatstroke/heat shock and implementation of measures against them. Also, it was shown that heatstroke and heat shock are different in the way of association. On the other hand, due to the limitations of available data, the consideration was not sufficient. In the future, it is necessary to refine the items and methods so that more specific examinations can be made, and to plan more specific policies for promoting actual implementation of measures against heatstroke and heat shock.

\section{Key Words}

Attitudes toward air-conditioning, Energy conservation behaviors, Heatstroke, Heat shock,

Questionnaire survey, Secondary analysis

本研究の目的は, 人々の冷暖房などのエネルギー利用に対する態度や省エネルギー行動が, 熱中症やヒートショックの健 康への影響についての認識や対策の実施とどのように関連しているかについて検討を行うことであった。本研究では, 2018 年 2 月に実施した旧東京電力供給エリア内の住民を対象としたライフスタイルに関する調査に回答した 3066 名を対象として 二次分析を行った。ロジスティック回帰分析の結果, 住宅の建築年や健康への態度・行動, 冷暖房への態度·行動, 省工 ネ行動が, 熱中症やヒートショックの健康への影響の認識や対策実施と関連することが示された。また, 熱中症とヒートショッ クでは, 関連の仕方に違いが見られることも示された。一方で, 利用できるデー夕の限界によって, その検討は十分なもの ではなかった。今後は, 項目や方法を洗練させ, より具体的な検討ができるように研究を発展させていくとともに, 生活者 の行動促進に向けた具体的な施策の立案とその検証が求められる。

キーワード

冷暖房への態度, 省エネルギー行動, 熱中症, ヒートショック, アンケート調査, 二次分析

$※ 1$ Tokyo Electric Power Company Holdings, Inc.

4-1 Egasaki-cho, Turumi-ku, Yokohama-shi, Kanagawa 230-0002, Japan

※2 TEPCO Energy Partner, Inc. 8-13-1, Ginza, Chuo-ku, Tokyo 104-0061, Japan

† Corresponding author: mukae.ryo@tepco.co.jp

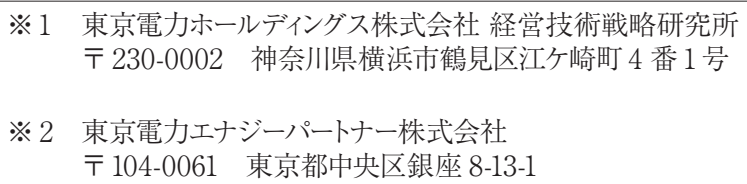




\section{1. 緒 言}

厚生労働省の人口動態統計によると, 2018 年 6 月から 9 月 までの夏季における熱中症の死亡者数は 1518 名 (速報值) であった ${ }^{1} 。$ また， 2008 年から 2017 年までの直近 10 年間 における 6 月から 9 月までの熱中症による死亡者数はの心゙ 7666 名, 年間合計ではのべ 8041 名 (ともに確定值) であり 1), 熱中症は，人々の豊かな暮らしを脅かす重大な健康リスクと して無視できないものであると考えられる。

他方, 冬季のヒートショックもまた, 人々の豊かな暮らし を損ねる健康リスクである。東京都健康長寿医療センターに よると， 2011 年の 1 年間で, 17000 名もの人がヒートショック に関連した入浴中急死をしたと推計されており，その死亡者 数は交通事故による死亡者数（4611 名）をはるかに上回る とされている2)。

こうした, 夏季の熱中症, 冬季のヒートショックを防ぐには, 居住環境における適切な温度の維持管理が重要だと考えら れる。

2013 年のデー夕に基づいた報告では，熱中症による死亡 者で発生場所が分かっている人のうち，84.0\%が「住居」で 発生していた(発生場所不詳を加えた場合は $46.9 \%$ が住居」 で発生） ${ }^{3)}$ 。また，住居内における高齢者の熱中症の発生場 所は「寝室」「居間」「台所」など多岐に渡っていることが報 告されている4)。これらを踏まえて考えると，居住環境にお ける温熱環境の改善は喫緊に取り組むべき課題だといえる。

ヒートショックについても，急激な温度差によって引き起こ されることから，入浴時のみならず，暖かい居間などの居室 からトイレに行く際，あるいは，起床時に布団から出る際な ど，居住環境のあらゆる場面で発生すると考えられる。国土 交通省の研究によると, 冬季の起床時室温が低いほど血圧 が高くなる傾向があり，その傾向は高齢者ほど顕著であるこ とが報告されている5)。こうした血圧の変化はヒートショック の発生に寄与しうる要因だと考えられる。さらに, ヒートショッ クに限らず，暖かい部屋ほど体の不調が改善したという報告 もあり ${ }^{6)}$, 夏季の熱中症と同様に，冬季におけるヒートショッ クをはじめとした健康に関する不調の発生リスクを低減させ るためには, 居住環境の適切な温度の維持管理が必要だと いえる。

居住環境においては, エアコンのほか, ストーブやヒーター, 扇風機などの機器の利用によって室温を適切に保つことが一 般的である。こうした冷暖房機器の効率的な活用は，手軽 にできる熱中症，ヒートショックの予防対策だと考えられる。 医療機関の熱中症患者を対象とした調査によると, 屋内環境 での熱中症の症例のうち，エアコンを使用していない場合の 方がより重症である人の割合が高いことが報告されている7)。

一方で, エアコンをはじめとした冷暖房機器に対して，「健 康に良くない」ものだとして, 忌避感を持っている人も少な くない。例えば，エアコン使用時の環境において，「エアコ ンは健康に良くない」という認識を抱いている人が回答者の うち53\%いたという報告がある ${ }^{4)}$ 。また，佐賀市近辺在住 の中高齢者（57〜8 歳）を対象としたアンケートでは，「暖
房された部屋にいることは健康のために良くない」という考

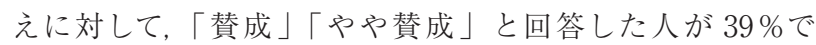
あったことが報告されている（「反対」「やや反対」の合計は 23\%) 8)。冷暖房に対するこうした認識が強いほど，熱中症 やヒートショックの発生リスクを高め, 健康を損ねる結果につ ながる可能性が考えられる。

上記の調査や研究結果を踏まえると, 熱中症やヒート ショックの発生リスクを低減させる, あるいはその重症化を 防ぐという観点から考えた場合に，人々の冷暖房の利用状 況やその利用についてどのような認識を持っているかについ て把握し, 適切な形での利用を促していくことは重要だとい える。一方で, こうした個人の冷暖房に対する意識や態度, 行動が, 実際の熱中症やヒートショックが健康に及ぼす影響 についての認識や, 何らかの対策の実施とどのように関連し ているかについてはこれまであまり検討されてこなかった。

そこで, 本研究では, 個人の冷暖房への態度・行動と, 熱中症・ヒートショックの健康への影響及び対策の実践の有 無との関連について検討を行った。この検討を通じて, 人々 の冷暖房などのエネルギー利用に対する意識とその活用が, 健康で豊かな暮らしにどのように関連しうるのかについての 示唆を得ることを本研究の目的とした。なお，後述のように， 本研究では既存の調查結果のデー夕を用いて二次分析を 行ったため, 十分に考察ができない部分が見られた。その ため, 本研究は, 今後の発展を見据えた仮説探索のための 資料としての位置づけとする。

\section{2. 調 査}

\section{1 調査対象及び分析対象者}

本研究では, 東京電力グループが「TOKYO LIFESTYLE 調査」の名称で経年的に実施している，一般消費者の生活 に対する意識やエネルギー使用状況等に関する情報収集の ための調査の 2018 年 2 月実施分（2017 年度）の回答デー夕 を利用し，上記の目的の元に二次分析を行った。

当該 TOKYO LIFESTYLE 調査の対象は, 旧東京電力供 給エリア内に居住する 20 ～69 歳 (性別・年代ごとに均等割 付）であり, Web アンケートシステムを用いて2回に分けて質 問項目を聴取した。この調査では, 一般生活者のライフス夕 イルをはじめとした様々な項目について質問を行ったが，本 研究では, そのうちの 1 回目の回答項目のみを用いたため, 1 回目の回答者 3066 名 (男性 1515 名, 女性 1551 名, 平均 年齢 45.43 歳, SD = 13.87）を分析対象者とした。

\section{2 調査項目}

本研究では, 調査の回答項目のうち, 性別 (1: 男性, 2 : 女性)，年代 (20 代から 60 代までの 10 歳ごとの区分)，金 融資産 (「1: 0 50 万円未満」「2: $50 \sim 100$ 万円未満」「3: $100 \sim 200$ 万円未満」「4:200～300 万円未満」「5：300～ 400 万円未満」「6:400 500 万円未満」「7: 500 600 万 円未満」「8:600 700 万円未満」「9:700 800 万円未満」 $\lceil 10: 800 \sim 900$ 万円未満」「11:900～1000 万円未満」「12: 
$1000 \sim 1500$ 万円未満」「13：1500～2000 万円未満」「14： $2000 \sim 3000$ 万円未満」「15：3000～ 5000 万円未満」「16 : 5000 万円以上」の 16 段階), 世帯収入 ( $「 1: 0 \sim 300$ 万円 未満」「2:300 350 万円未満」「3:350 400 万円未満」「4: $400 \sim 450$ 万円未満」「5：450～500 万円未満」「6:500～ 600 万円未満」「7:600 700 万円未満」「8: 700 800 万 円未満」「9:800 900 万円未満」「10:900 1000 万円未満」 $\lceil 11: 1000 \sim 1500$ 万円未満」「12:1500 万円以上」の 12 段階) といった個人の属性に関する設問に加えて, 生活水準の主 観的認識に関する1項目（「仮に, 現在の日本の社会全体を, 次の $6 つ の$ 層にわけるとすると, あなたのご家庭はこのどれ に入ると思いますか」という設問に対して「6:上「5:中の上」 $\lceil 4:$ 中の中」「3: 中の下」「2:下の上」「1:下の下」の 6 段 階で回答), 健康への態度・行動に関する 13 項目 (「5: 非常 にあてはまる」「4: まああてはまる」「3：どちらともいえない」 「2：あまりあてはまらない」「1：全くあてはまらない」の 5 件 法), 冷暖房への態度・行動に関する 17 項目 (「5：非常にあ てはまる」「4:まああてはまる」「3:どちらともいえない」「2: あまりあてはまらない」「1: 全くあてはまらない」の5 件法)， 様々な省エネルギー行動（以下，「省エネ行動」と表記）の 取組の有無に関する 39 項目(「冷房の設定温度を高めにする」 「エアコンのフィルターをこまめに掃除する」といった冷暖房 に関する省エネ行動及び「シャワーを使用する際に水を流し たままにしない」「省エネのために, 白熱灯や電球型蛍光灯 をLED 電球に取り替えている」といった冷暖房以外の省エ ネ行動について, それぞれ実施しているものをチェックして もらう2 件法), 熱中症及びヒートショックについての健康へ の影響の認識及び対策実施の有無の項目(「熱中症/ヒート ショックの健康への影響について，あなたはどう考えていま すか」という設問に対して,「健康への影響を分かっており, 対策をとるよう気を付けている」「健康への影響を分かって いるが何もしていない」「分からない」からそれぞれ1つ選択 して回答）を分析に用いた。健康への態度・行動に関する 項目, 冷暖房への態度・行動に関する項目, 省エネ行動の 項目については, 後述の手続きによって絞り込みを行った（最 終的に用いた省エネ行動の項目については Table 1 を, 健康 への態度・行動に関する項目及び冷暖房への態度・行動に 関する項目については Table 3 及びTable 4 を参照されたい)。 また, 上記項目に加えて, 冷暖房への態度・行動との関 連が予想される変数として, 乳幼児 (未就学児) または高齢 者（65 歳以上）との同居の有無, 都県単位の住宅の省エネ ルギー基準に㧍ける地域区分（調査対象となった地域の中 で, 都県単位では, 栃木県のみ「4」地域, 他の都県は「5, 6」地域) ${ }^{9)}$ 及び, 省エネルギー施策に基づいた住宅の建築 年区分 (「2013 年以降」(改正省エネルギー基準)，「1999 2012 年」(次世代省エネルギー基準),「1992 1998 年」(新 省エネルギー基準），「1980～1991 年」（旧省エネルギー基
準),「1979 年以前」(旧省エネルギー基準以前)，「分からない」 の6区分）の情報についても用いた。

\section{3 分析方法}

省エネ行動については, 調査内で聴取された計 39 項目に ついて, まず, 項目の内容を見ながら, 他と比較して大掛か りな行動(「節電のために太陽光発電システムを導入した」等) を除外した上で, 冷暖房に関する省エネ行動とそれ以外の 省エネ行動に分類した。次に，2つの分類について，それ ぞれ Kuder-Richardsonの第 20 公式 (KR-20) を用いて信頼 性係数を算出し, その值が改善するように項目の取捨選択を 行った。結果, 冷暖房に関する省エネ行動が計 15 項目, そ の他の省エネ行動が計 20 項目となり (Table 1), 信頼性係 数はそれぞれ.84 と.86であった。冷暖房に関する省エネ行 動とその他の省エネ行動それぞれについて，実施していると 回答した項目の合計数を算出し, 各回答者がどれくらい省エ ネ行動を実践しているかの指標として用いた。

健康への態度・行動に関する項目及び冷暖房への態度・ 行動に関する項目については, 後述の因子分析の結果に基 づいて回答者ごとに因子得点を算出し, 各回答者の健康へ の態度・行動及び冷暖房への態度・行動の指標とした。

熱中症及びヒートショックの健康への影響の認識及び対 策実施の有無に関しては，以下のように再コード化した。(1) 健康への影響の認識については,「分からない」を 0 ,「健 康への影響を分かっており，対策をとるよう気を付けている」 及び「健康への影響を分かっているが何もしていない」のど ちらかに回答した場合を1として 2 值データ化し, 熱中症, ヒー トショックそれぞれに対する健康への影響の認識の有無の 指標とした。(2) 対策実施については (1) で「1」に分類され た回答者のうち，「健康への影響を分かっており，対策をと るよう気を付けている」と回答した場合を 1 ,「健康への影 響を分かっているが何もしていない」と回答した場合を 0 と して 2 值データに変換し, 熱中症及びヒートショックの対策 実施の有無の指標として用いた。

続いて, 個人属性 (性別, 年代, 主観的生活水準, 金融 資産, 世帯収入), 乳幼児・高齢者との同居有無 (それぞれ 同居している場合を 1 , していない場合を 0 ), 住宅の省エネ ルギー基準における地域区分（「4」地域が 1 ，「5，6」地域 が0), 省エネルギー施策に基づいた住宅の建築年区分, 健 康への態度・行動及び冷暖房への態度・行動の各因子得点, 冷暖房に関する省エネ行動及びその他の省エネ行動の合計 数を独立変数, 熱中症及びヒートショックの健康への影響 の認識有無, 対策実施の有無をそれぞれ従属变数としてロ ジスティック回帰分析を行い, 各独立変数と熱中症/ヒート ショックの健康への影響の認識の有無及び対策実施の有無 との関連について検討を行った。 
Table 1 Energy conservation behaviors

\begin{tabular}{l}
\hline \multicolumn{1}{c}{ items } \\
\hline Energy conservation behavior (About cooling and heating) \\
1 Reduce time and duration of cooling \\
2 Reduce a number of rooms to be cooled \\
3 Increase the cooling temperature \\
4 Weaken air volume of cooling \\
5 Reduce time and duration of heating \\
6 Reduce a number of rooms to be heated \\
7 Decrease the heating temperature \\
8 Wear a lot of clothes not to overuse heating at home \\
9 Try to keep a air conditioner filter clean \\
10 Set cooling temperature to $28^{\circ} \mathrm{C}$ or higher \\
11 Use a air conditioner during limited time \\
12 Avoid using an air conditioners by using other cooling \\
equipments such as a fan \\
13 Use goods for heat stroke prevention (goods that cool \\
one's neck and shoulders) and refrain from using air \\
conditioners \\
14 Family members gather in one place as much as \\
possible so as not to use cooling in multiple rooms \\
15 Try to soften the sunlight with green walls or bamboo \\
blinds, etc.
\end{tabular}

Energy conservation behavior (Except for cooling and heating)

1 Use a water saving showerhead, etc.

2 Use leftover bath water for laundry

3 Reduce usage of bath water

4 Reduce a number of taking a bath

5 Don't leave water running when taking a shower

6 Try to wash in bulk as possible when using a washing machine

7 Try to reduce a certain amount of water used for cooking or washing

8 Don't leave water running when brushing my teeth or washing my face

9 Adjust the temperature of heating toilet seat according to the season

10 In winter, I change the setting temperature of a refrigerator and adjust so as not to be too cold

11 Try to conserve fire power of a gas burner

12 Don't keep warm a rice cooker for a long time

13 Don't keep warm an electric pot for a long time, or choose an energy saving type

14 Replace incandescent lamps with (bulb-shaped) fluorescent lamps

15 There is a place where LED lights are installed at home

16 Replace incandescent or fluorescent lights with LED lights to save energy

17 Try to minimize lighting by thinning out or dimming

18 During the daytime, I turn off lights as much as possible

19 Stop watching TV aimlessly and turn it off when not necessary

20 For saving energy, I replaced equipments with big power consumption such as air conditioner or refrigerator with energy saving types

\section{3. 結果と考察}

\section{1 結 果}

\subsection{1 基本統計量の算出}

分析に用いた各変数の基本統計量について, Table 2 にま とめた（観測変数でない健康への態度・行動及び冷暖房へ の態度・行動の各因子得点は除く)。なお, 主観的生活水 準，金融資産，世帯収入，冷暖房に関する省エネ行動及び その他の省エネ行動の合計数については，単位に意味がな く，尺度として標準化された項目でもないため，ロジスティッ ク回帰分析の際には值の標準化 (平均を 0 , 標準偏差を 1 に線形変換）を行った上で独立変数として投入した。また, 住宅の建築年区分については，「分からない」と回答した対 象者の割合が 470 名 (15.3\%) と比較的多く，回答者の何 らかの特徵が反映されている可能性が考えられたことから, 「分からない」を除外した順序尺度として扱うのではなく,「分 からない」の回答も含めた全 6 カテゴリの名義尺度として扱っ た。

\section{1 .2 因子分析の結果}

健康への態度・行動及び冷暖房への態度・行動のそれぞ れの項目について因子分析を行った。まず, 因子数の決定を 行った。健康への態度・行動に関する 12 項目 ( 1 項目は固 有商品・サービス名が入っていたため分析から除外）と冷暖 房への態度・行動に関する 17 項目についてそれぞれ固有值 及びスクリープロットを確認しながら因子数を決定し，その 因子数の仮定の下で探索的因子分析を行った（最尤法, プ ロマックス回転)。上記の手続きを繰り返しながら, 解釈の しやすさ等を勘案しながら項目を取捨選択し，最終的に健 康への態度・行動について 9 項目 3 因子, 冷暖房への態度・ 行動について 12 項目 3 因子を採用した。続いて, それぞれ の因子で負荷量の高い項目の内容を確認し, 健康への態度.

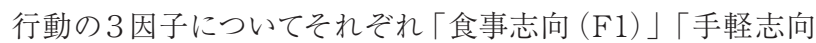
(F2)」「運動志向 $(F 3) 」$ 命名, 冷暖房への態度・行動の 3 因子についてはそれぞれ「冷暖房忌避 $(\mathrm{F} 1) 」 「$ 暖房積極 利用 (F2)」「冷房積極利用 (F3)」と命名し, 各因子につい て回答者ごとの因子得点を算出した (回帰法にて推定)。分 析結果を Table 3 及び Table 4 に示す。

\subsection{3 ロジスティック回帰分析の結果}

個人属性（性別，年代，主観的生活水準，金融資産，世 帯収入) , 乳幼児及び高齢者との同居有無, 住宅の省エネル ギー基準に扮ける地域区分, 省エネルギー施策に基づいた 住宅の建築年区分（基準カテゴリ：「2013 年以降」），健康 への態度・行動及び冷暖房への態度・行動に関するそれぞ れ3 因子の各因子得点, 冷暖房に関する省エネ行動及びそ の他の省エネ行動の合計数を独立変数とし, 熱中症及びヒー トショックの健康への影響の認識の有無, 対策実施の有 無をそれぞれ従属変数としてロジスティック回帰分析を行っ た。多重共線性のチェックとして, VIF（Variance Inflation Factor：分散拡大係数）を算出し, すべて 3 未満であるこ とを確認した上で，オッズ比 (Odds Ratio：OR) 及び疑似 決定係数である Nagelkerkeの $R^{2}$ を算出した。分析結果を 
Table 2 Basic statistics $(N=3066)$

\begin{tabular}{|c|c|c|c|c|c|c|c|}
\hline & & & n (\%) & mean & $S D$ & $\min$ & $\max$ \\
\hline \multirow[t]{2}{*}{ Sex } & \multicolumn{2}{|l|}{ Male } & 1515 (49.4) & - & - & - & - \\
\hline & \multicolumn{2}{|l|}{ Female } & $1551(50.6)$ & - & - & - & - \\
\hline \multirow[t]{5}{*}{ Age } & \multicolumn{2}{|l|}{$20 \mathrm{~s}$} & $547(17.8)$ & - & - & - & - \\
\hline & \multicolumn{2}{|l|}{$30 \mathrm{~s}$} & $629(20.5)$ & - & - & - & - \\
\hline & \multicolumn{2}{|l|}{$40 \mathrm{~s}$} & $629(20.5)$ & - & - & - & - \\
\hline & \multicolumn{2}{|l|}{$50 \mathrm{~s}$} & $633(20.7)$ & - & - & - & - \\
\hline & \multicolumn{2}{|l|}{$60 \mathrm{~s}$} & $628(20.5)$ & - & - & - & - \\
\hline \multicolumn{3}{|l|}{ Subjective level of living } & $-(-)$ & 3.37 & 1.11 & 1 & 6 \\
\hline \multicolumn{3}{|l|}{ Financial asset } & $-(-)$ & 7.49 & 5.34 & 1 & 16 \\
\hline \multicolumn{3}{|l|}{ Household income } & $-(-)$ & 5.85 & 3.57 & 1 & 12 \\
\hline \multicolumn{3}{|c|}{ Living with babies or infants } & $284(9.3)$ & - & - & - & - \\
\hline \multicolumn{3}{|c|}{ Living with people over 65} & $924(30.1)$ & - & - & - & - \\
\hline \multirow{2}{*}{$\begin{array}{l}\text { Area division of energy } \\
\text { efficiency standards }\end{array}$} & \multicolumn{2}{|l|}{ Area 4} & $252(8.2)$ & - & - & - & - \\
\hline & \multicolumn{2}{|l|}{ Area 5 or 6} & $2814(91.8)$ & - & - & - & - \\
\hline \multirow[t]{6}{*}{ house construction year } & \multicolumn{2}{|l|}{2013 or later } & $288(9.4)$ & - & - & - & - \\
\hline & \multicolumn{2}{|l|}{$1999-2012$} & $975(31.8)$ & - & - & - & - \\
\hline & \multicolumn{2}{|l|}{$1992-1998$} & $503(16.4)$ & - & - & - & - \\
\hline & \multicolumn{2}{|l|}{$1980-1991$} & $544(17.7)$ & - & - & - & - \\
\hline & \multicolumn{2}{|l|}{1979 or earlier } & $286(9.3)$ & - & - & - & - \\
\hline & \multicolumn{2}{|l|}{$\mathrm{DK}$} & $470(15.3)$ & - & - & - & - \\
\hline \multirow{2}{*}{$\begin{array}{l}\text { Energy conservation } \\
\text { behaviors }\end{array}$} & \multicolumn{2}{|c|}{ About cooling and heating } & $-(-)$ & 3.96 & 3.48 & 0 & 15 \\
\hline & \multicolumn{2}{|c|}{ Except for cooling and heating } & $-(-)$ & 4.69 & 4.29 & 0 & 20 \\
\hline \multirow[t]{3}{*}{ Heatstroke } & \multirow{3}{*}{\multicolumn{2}{|c|}{$\begin{array}{ll}\begin{array}{l}\text { Recognition of } \\
\text { wealth risk }\end{array} & \text { w/O Implemention of measures } \\
\text { DK } & \end{array}$}} & $1800(58.7)$ & - & - & - & - \\
\hline & & & 877 (28.6) & - & - & - & - \\
\hline & & & $389(12.7)$ & - & - & - & - \\
\hline \multirow[t]{3}{*}{ Heat shock } & \multirow{3}{*}{$\begin{array}{l}\text { Recognition of } \\
\text { health risk } \\
\text { DK }\end{array}$} & w/ Implemention of measures & $1080(35.2)$ & - & - & - & - \\
\hline & & w/o Implemention of measures & $1367(44.6)$ & - & - & - & - \\
\hline & & & $619(20.2)$ & - & - & - & - \\
\hline
\end{tabular}

DK = "don't know", w/ = "with", w/o = "without"

Table 3 Factor analysis of attitudes toward health $(N=3066)$

\begin{tabular}{|c|c|c|c|c|}
\hline & & \multicolumn{3}{|c|}{ Factors } \\
\hline & & $\mathrm{F} 1$ & $\mathrm{~F} 2$ & F3 \\
\hline & & Food-oriented & $\begin{array}{c}\text { Easy way- } \\
\text { oriented }\end{array}$ & Fitness-oriented \\
\hline 1 & Care about a balance of meals (take more vegetables, etc.) & .91 & -.03 & -.17 \\
\hline 2 & Try to eat more vegetables for my health & .85 & -.03 & .02 \\
\hline 3 & Always have a health conscious meal & .68 & .10 & .07 \\
\hline 4 & Use vitamin preparations for nutritional support & .00 & .92 & -.05 \\
\hline 5 & Regularly take nutrition drinks and health supplements & -.06 & .75 & .04 \\
\hline 6 & Take supplements and health foods for my health & .10 & .69 & .03 \\
\hline 7 & Exercise for my health & .07 & -.10 & .82 \\
\hline 8 & Pay attention to lifestyle diseases, and regularly exercise and control meals & -.20 & .11 & 67 \\
\hline 9 & Regularly go to a sports gym & .33 & .03 & .52 \\
\hline \multirow{2}{*}{\multicolumn{2}{|c|}{ Factor correlation }} & & \multirow[t]{2}{*}{.25} & .55 \\
\hline & & & & .40 \\
\hline
\end{tabular}


Table 4 Factor analysis of attitudes toward air-conditioning $(N=3066)$

\begin{tabular}{|c|c|c|c|c|}
\hline & & \multicolumn{3}{|c|}{ Factors } \\
\hline & & $\mathrm{F} 1$ & $\mathrm{~F} 2$ & F3 \\
\hline & & $\begin{array}{c}\text { Avoidance of } \\
\text { air-conditioning }\end{array}$ & $\begin{array}{c}\text { Proactive use of } \\
\text { heating }\end{array}$ & $\begin{array}{c}\text { Proactive use of } \\
\text { cooling }\end{array}$ \\
\hline 1 & Cooling is expensive and luxurious & .84 & .06 & -.04 \\
\hline 2 & Cooling is a waste of energy & .81 & -.04 & -.05 \\
\hline 3 & Heating is a waste of energy & .76 & -.20 & .14 \\
\hline 4 & Heating is expensive and luxurious & .75 & .01 & .08 \\
\hline 5 & Cooling is not good for my health & .57 & .22 & -.16 \\
\hline 6 & With heating, I can live comfortably & .02 & .93 & -.03 \\
\hline 7 & With heating, I can live healthily & .00 & .92 & -.05 \\
\hline 8 & Can’t live without heating & -.02 & .69 & .15 \\
\hline 9 & Habitually use heating & .01 & .53 & .22 \\
\hline 10 & Can’t live without cooling & -.01 & .02 & .88 \\
\hline 11 & Habitually use cooling & -.02 & .01 & .82 \\
\hline 12 & With cooling, I feel comfortable because I can sleep enough during the night & .03 & .19 & .57 \\
\hline \multicolumn{2}{|c|}{ Factor correlation } & & .15 & $\begin{array}{l}.10 \\
56\end{array}$ \\
\hline
\end{tabular}

Table 5 に示す。

熱中症の健康への影響の認識有無が従属変数の場合に ついては，省エネルギー施策に基づいた住宅の建築年区分 (「2013 年以降」が基準カテゴリ）において，投入したカテ ゴリのうち,「分からない」で有意な負の関連が見られた $(p$ $<.05)$ 。健康への態度・行動では,「食事志向 $(\mathrm{F} 1) 」 て ゙$ 有 意な正の関連 $(p<.001)$, 「運動志向 (F3)」で有意な負の 関連 $(p<.001)$ が見られた。冷暖房への態度・行動では, 「暖房積極利用 (F2)」「冷房積極利用 (F3)」で有意な正の

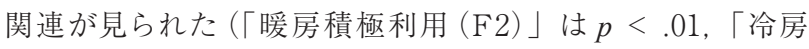
積極利用 $(\mathrm{F} 3) 」$ は $p<.05)$ 。省エネ行動では, 冷暖房に 関する省エネ行動, 冷暖房以外の省エネ行動でともに有意 な正の関連が見られた (どちらも $p<.001) 。$ Nagelkerkeの $R^{2}$ は.34であった。

熱中症の対策の実施有無が従属変数の場合については, 個人属性のうち, 性別（1：男性，2：女性）で有意な正の関 連が見られ，金融資産で有意な負の関連が見られた（どちら も $p<.05)$ 。また, 健康への態度・行動の 3 因子のうち, 「食 事志向 $(\mathrm{F} 1) 」$ で $p<.001$, 「手軽志向 $(\mathrm{F} 2) 」 て ゙ ~ p<.01$ で それぞれ有意な正の関連が見られた。冷暖房への態度・行 動では，「冷暖房忌避 $(\mathrm{F} 1) 」 て ゙$ 有意な負の関連が見られ $(p$ $<.01)$, 「暖房積極利用 (F2)」「冷房積極利用 (F3)」では 有意な正の関連が見られた（それぞれ $p<.05$ と $p<.01) 。$ 省エネ行動では, 冷暖房に関する省エネ行動, 冷暖房以外 の省エネ行動でともに有意な正の関連が見られた（どちらも $p<.001)$ 。なお, 主観的生活水準, 高齢者 (65 歳以上) との同居, 建築年区分の「分からない」では, 有意な傾向 $(p$ <.10) が見られた（主観的生活水準及び高齢者（65歳以上） との同居では正の関連，建築年区分の「分からない」では 負の関連)。Nagelkerkeの $R^{2}$ は.20であった。

ヒートショックの健康への影響の認識有無が従属変数の 場合については，個人属性のうち，性別で有意な負の関
連が見られ $(p<.05)$, 年代で有意な正の関連が見られた $(p<.001)$ 。また, 住宅の建築年区分において, 投入したカ テゴリのうち,「分からない」で有意な負の関連が見られた $(p<.01)$ 。健康への態度・行動では, 「食事志向 $(\mathrm{F} 1) 」 て ゙$ 有意な正の関連 $(p<.01)$ が見られた。冷暖房への態度・ 行動では,「冷房積極利用 (F3)」で有意な正の関連が見ら れた $(p<.01)$ 。省エネ行動では, 冷暖房に関する省エネ行 動, 冷暖房以外の省エネ行動でともに有意な正の関連が見 られた (どちらも $p<.001)$ 。なお, 健康への態度·行動の「運 動志向 (F3)」では, 有意な傾向 $(p<.10)$ が見られた（負 の関連)。Nagelkerkeの $R^{2}$ は.21であった。

ヒートショックの対策の実施有無が従属変数の場合につい ては, 高齢者（65 歳以上）との同居で正の関連が見られた $(p<.001)$ 。また, 住宅の建築年区分では, 全てのカテゴ リに怙いて有意な負の関連が見られた（「1999〜2012 年」 及び「分からない」では $p<.01$ ，それ以外のカテゴリでは

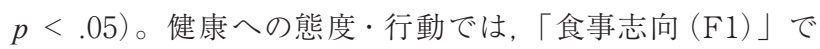
正の関連が見られた $(p<.001)$ 。冷暖房への態度・行動 では有意な関連が見られず, 省エネ行動では, 冷暖房以外 の省エネ行動で有意な正の関連が見られた $(p<.001)$ 。な お，健康への態度・行動の「手軽志向 $(\mathrm{F} 2) 」 て ゙$ 有意な傾向 $(p<.10)$ が見られた (正の関連)。Nagelkerkeの $R^{2}$ は.11 であった。

\section{2 考 察}

\subsection{1 熱中症の健康への影響の認識の有無との関連につい 乙}

熱中症の健康への影響の認識有無と個人属性（性別，年 代，主観的生活水準，金融資産，世帯収入）との間には有 意な関連は見られなかった。一方, 省エネルギー施策に基づ いた住宅の建築年区分との間の関連では，「2013 年以降」を 基準カテゴリとした場合に，「分からない」のカテゴリにおい 


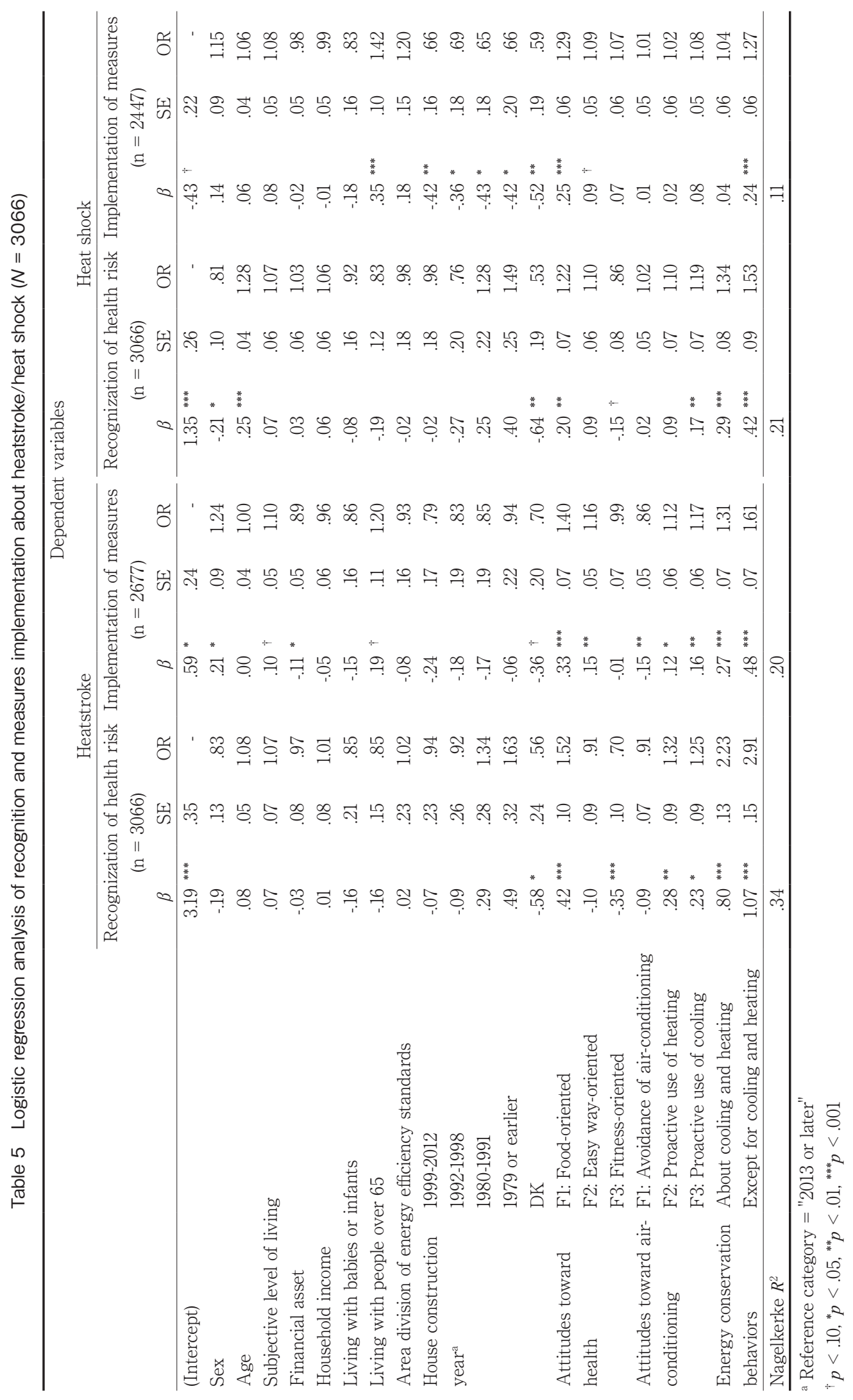


てのみ有意な負の関連が見られた。このことからは，自身の 住んでいる家の建築年を把握していない人は,「2013 年以降」 の住宅に住んでいる人よりも熱中症の健康への影響を認識し ている割合が低いことが示されたといえる。さらに，他の建 築年では有意な関連がないことを踏まえると，建築年を把握 していない人は, 建築年にかかわらず把握している人よりも 熱中症の健康への影響を認識している割合が低い可能性が 示されたといえる䀧注1)。ただし，調査において「分からない」 と回答しやすい特性によって，見かけ上の関連となっている 可能性も考えられるため, 解釈に留意すべきであろう。また, 本研究は一時点の調査結果を用いているため, 住宅に対す る意識や理解が低いことが熱中症の健康リスクへの認識を 抑制しているのか, 熱中症の健康リスクに対する認識が低い ことが住宅に対する意識や理解の低さにつながっているの か, あるいは, 背後に今回測定されていない別の要因があり, 見かけ上の関連が示されているのかについて検討することは できない。こうした関連の詳細について把握することは，生 活者の健康リスク低減や快適な生活環境の提供を考える上 で重要であり, 今後, 具体的に検討していくことが求められ る。

住宅の建築年区分について, 個々のオッズ比を確認すると, $\lceil 2013$ 年以降」が基準の場合には統計的に有意ではないも のの, 「1999〜2012 年」及び「1992〜1998 年」ではオッズ 比が1未満（それぞれ.94 と.92）であり，「1980〜 1991 年」 及び「1979 年以前」では1より大きかった（それぞれ 1.34 と 1.63)。そこで，オッズ比が最も小さかった「1992〜1998 年」 を基準カテゴリとして改めてロジスティック回帰分析を行っ たところ，「1979 年以前」で有意な正の関連，「分からない」 で有意な負の関連が見られた（ともに $p<.05 ，$ オッズ比は それぞれ 1.77 と.61)。この結果からは, 住宅の建築年を把 握している人の中では, 建築年が 1979 年以前の特に古い住 宅に住んでいると, 他の独立変数が一定の場合に, 熱中症 の健康への影響について認識している割合が高いと考えら れる。これは, 建物が古く断熱性能が相対的に低いことで, 夏季の外気温の影響を受けやすく，室内における暑さを体 感する機会が多くなり, 結果として熱中症について意識しや すくなっているのではないかと考えることができる。

熱中症の健康への影響の認識有無と健康への態度・行動 との関連では,「食事志向 (F1)」で有意な正の関連が見ら れた一方で,「手軽志向 (F2)」では関連は見られず,「運動 志向 (F3)」では有意な負の関連が見られた。このことは, 健康に対する意識が高く, 行動しているような人であっても, そのアプローチ方法によって熱中症の健康リスクに対する認 識が異なっている可能性を示唆するものである。「食事志向 (F1)」については, 毎日の食事の中で健康を意識し, 気を つけているという点において, 同じょうに日々の生活の中で

脚注 1) 後述の通り, Table 5 の建築年区分で最もオッズ比が小 さかった「1992〜1998年」を基準カテゴリとした場合 でも「分からない」のカテゴリで有意な負の関連が見ら れており,この可能性を支持する結果となった。
の配慮が求められる熱中症の健康リスクに対する認識と似て おり，そうした日々の生活の中での健康への配慮という点に おいて, 何らかの共通要因があるのかもしれない。また,「運 動志向(F3)」では負の関連が見られたが, これは, 運動によっ て自身の体力や健康に対する自信や実感を有していること が,「自分は大丈夫」というような熱中症の健康リスクの軽 視につながっている可能性が考えられる。個人の健康に対す るアプローチの違いと健康リスクに対する認識の関連につい ては, 今後より掘り下げて検討していくことが必要であろう。

冷暖房への態度・行動との関連では,「冷暖房忌避 $(\mathrm{F} 1) 」$ では有意な関連は見られず,「暖房積極利用 (F2)」「冷房 積極利用 (F3)」では有意な正の関連が見られた。「暖房積 極利用 (F2)」及び「冷房積極利用 (F3)」との正の関連に ついては，冷暖房を積極的に利用してその快適さを享受す ることが, 住居における温熱環境に対する重要性の認識を 高め, 熱中症の健康リスクに対する認識につながったという 流れと, 熱中症の健康リスクに対する認識があることによっ て, 積極的に冷暖房を利用しているという反対方向の流れ の両方の可能性が考えられる。また, 「冷房積極利用 (F3)」 だけでなく,「暖房積極利用 (F2)」も熱中症の健康リスク の認識との関連が示されている点については, 夏季に冷房に よって室温を下げるというだけでなく, 暖房も含めた温度管 理への意識が重要である可能性を示唆するものといえよう。 これらの関連の詳細なプロセスを検討していくことは今後の 重要な課題である。

省エネ行動との関連では, 冷暖房に関する省エネ行動, その他の省エネ行動のどちらも有意な正の関連が見られた。 オッズ比は, 冷暖房に関する省エネ行動で 2.23 , その他の 省エネ行動では 2.91 であった。この結果からは, 冷暖房に 関するものであれ, それ以外のものであれ, 省エネ行動をとっ ている人の方が, 熱中症の健康への影響について認識して いる割合が高いことが示された。一見すると, 省エネ行動と 熱中症の健康への影響の認識との間に何らかの関連がある とは考えにくいものの, どちらも, 毎日の生活の中で意識し ながら過ごすことが求められるという点では共通である。こ の共通点を踏まえると, これらの関連の背後には, そうした 意識を日々の生活の中で維持できるだけの心理的あるいは 時間的な余裕といった共通の要因があるのかもしれない。省 エネ行動を含めた環境配慮行動の規定因について, 広瀬 ${ }^{10)}$ は先行研究のレビューを通して, 態度の決定と行動意困の決

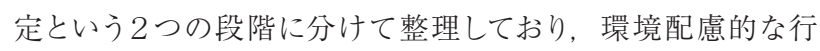
動意図に影響する要因として, 行動評価（実行可能性評価, 便益・費用評価, 社会規範評価) を挙げている。この行動 評価のうち, 特に実行可能性評価と便益・費用評価は, 心 理的なものも含めた生活上の様々な資源の多鿒に影響を受け るものと推測され，例えば，前述のような生活に対する余裕 があり, 心理的, 時間的な資源がある場合, 実行可能性評 価及び便益・費用評価が向上し, それが省エネ行動を増加 させ，反対に生活に対する余裕がなく，資源にそしい場合 には実行可能性評価及び便益・費用評価が低下し, 省エネ 
行動の抑制につながるというような可能性が考えられる。他 方, 熱中症の健康への影響についての認識にそうした生活 に対する心理的あるいは時間的な余裕がどのように関連する のかについてはこれまであまり検討されていない。本研究で は, 主観的生活水準に関する項目を独立変数として用いて いるものの, その内容は「仮に, 現在の日本の社会全体を, 次の 6 つの層にわけるとすると, あなたのご家庭はこのどれ に入ると思いますか。というものであり，こうした生活の中 での余裕について把握できるような項目とはいいがたいもの であった。上記のような背後要因の有無やその関連について より詳細に検討していくためには, 設問の見直しや追加等を 含めた研究計画の立案が求められる。

\section{2 .2 熱中症の対策実施の有無との関連について}

熱中症の健康への影響について認識している人を対象と して $(n=2677)$, 対策実施の有無との関連について見ると, 個人属性では性別（1：男性，2：女性）で有意な正の関連 が見られ，金融資産では有意な負の関連が見られた。性別 との関連では, 男性よりも女性の方が熱中症の対策を実際 にとろうと気をつけていることが示されたといえる。一般に, 熱中症対策としては, こまめに水分や塩分, 経口補水液等 を補給することや, 通気性の良い衣服の着用, 冷却グッズ（保 冷剂や冷却シート等) の利用といったものがあるほか, 屋内 では, 気温や湿度の確認に加えて, エアコンや扇風機といっ た冷房機器の利用などが挙げられる ${ }^{11}$ 。本研究で分析に用 いたデータでは, 具体的な対策の内容が聴取されていなかっ たため, 性別によって具体的にどのような対策の仕方の違い があるかについては分からないものの, 男性と比較して女性 の方が, こうした対策を実践しやすい可能性があると考えら れる。一方, 金融資産との関連については, 金融資産が多 いほど，熱中症への対策を実施していないということが示さ れた。金融資産が熱中症対策を抑制するというのは直感的 には関連を考えづらいものの，十分な金融資産を持ち，金 銭的あるいは物質的に豊かな生活を送っている場合, そも そも熱中症が発生しやすい環境に自分の身を置くことが少な く，上記のような熱中症への対策を意識して実施することが 少ないといったような状況があるかもしれない。また, 今回 用いたデータでは, 調査時に「対策」がどのようなものか具 体的な例示などもしていなかったため, 実際には熱中症対策 になるようなことをしていても，それが対策として意識されて いない可能性も考えられる。例えば, 快適に過ごすことを目 的として冷房を積極的に利用していても, それが熱中症対策 になっていると意識されていないような場合である。後述の ように，対策について具体的な説明やその内容に関するデー 夕を用いることができなかった点は本研究における限界であ り, 今後に向けた課題といえる。

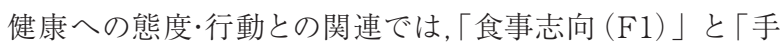
軽志向 (F2)」で有意な正の関連が見られた。前述の通り, 健康への影響の認識を従属変数とした場合は,「手軽志向 (F2)」では有意な関連が見られなかったが, 健康への影響 について認識している人の中では,「手軽志向 (F2)」が熱
中症の対策の実践に関連することが示された。健康への態 度・行動における「手軽志向 (F2)」が高い人は, 健康を意 識しつつも，食事や運動のように手間のかかることではなく， 簡単に実践することを重視しているのではないかと考えられ， 熱中症においても，健康への影響についてきちんと知りたい， しっかりと理解したいということよりも，対策として手軽で簡 単にできることは何か, というアプローチをしやすいのでは ないだろうか。その結果, 健康への影響の認識の有無では 関連が見られなかった一方で, 実践の有無において関連が 見られたのではないかと考えることができる。この点につい ても，対策の内容を具体的に聴取して関連を検討するなど, 研究をより発展させて検証していくことが求められる。

熱中症の対策実施の有無と冷暖房への態度・行動との関 連では,「冷暖房忌避 (F1)」で有意な負の関連が見られ,「暖 房積極利用 (F2)」「冷房積極利用 (F3)」で有意な正の関 連が見られた。健康への影響についての認識では「冷暖房 忌避 $(\mathrm{F} 1) 」 は$ 関連が見られなかったが, 実際に対策を行う という点においては, 冷暖房の利用を避けるような態度・行 動は, 対策実施を抑制する可能性があることを支持する結果 といえる。前述のように, 屋内における熱中症対策の具体的 な方法として, エアコンや扇風機といった冷房機器の利用は 有効な手段となる。冷暖房に対して忌避的であるほど，こう した冷房機器を利用する形での対策を実践しにくく，結果と して対策実施の抑制につながるのではないかと考えられる。 また,「暖房積極利用 (F2)」「冷房積極利用 (F3)」につい ては, 冷暖房機器に対する親和性が高いほど, 積極的にこ れらを利用した室温管理を行うと考えられることから, 対策 実施促進に寄与しうるのではないかといえる。

熱中症の対策実施の有無と省エネ行動との関連では, 健 康への影響についての認識と同様に, 冷暖房に関する省エ ネ行動, 冷暖房以外の省エネ行動のどちらも有意な正の関 連が見られた。オッズ比は, 冷暖房に関する省エネ行動で 1.31, その他の省エネ行動では 1.61 と健康への影響の認識 の有無を従属変数とした場合よりも小さいものの, 省エネ行 動を実践している人ほど, 熱中症の対策についても実施して いることが示されたといえる。冷暖房の省エネ行動について は, 冷房機器の利用に対して抑制的になると考えられること から, 直感的には対策実施の促進につながるとは考えづらい ものの, 前述のように, 省エネ行動と熱中症などの健康リス クの認識, さらにその対策の実施に共通の背後要因として, 生活上の心理的あるいは時間的な余裕があり，それがそれ ぞれの行動に対する実行可能性評価及び便益・費用評価の 高さをもたらすことによって, 両者の間に正の関連が見られ た可能性がある。

\subsection{3 ヒートショックの健康への影響の認識の有無との関 連について \\ ヒートショックの健康への影響の認識有無と個人属性との} 関連では, 性別（男性=1, 女性 $=2$ ） で有意な負の関連が 見られ，年代では有意な正の関連が見られた。このことか らは，女性よりも男性の方が，また，年代が高いほどヒート 
ショックの健康への影響の認識を持ちやすいことが示された といえる。ヒートショックは温度差による急激な血圧の変化 によってもたらされるが，血圧の急上昇は心筋梗塞などのリ スクを高める。心筋梗塞の患者数は男性の方が女性よりも多 く12), ヒートショックは，心筋梗塞のような命に係わる重大 な健康被害として認識されている可能性があるのではないか と考えられる。年代については，ヒートショックが高齢者で 患者数が多いことから，年代が高くなるほど，ヒートショッ クやその要因である血圧の変化に対する意識が高くなるので はないかといえる。血圧に関して, 本研究で用いたTOKYO LIFESTYLE 調査の別項目で「毎日，血圧測定しているか」 について 2 件法で行動実施の有無を聴取している。この結果 では，年代が高いほど，毎日血圧を測定している人の割合 が高いことが示されている (Fig. 1参照。フィッシャーの直 接確率検定では, 年代による比率の差は $p<.001$ で有意)。

ヒートショックの健康への影響の認識有無と省エネルギー 施策に基づいた住宅の建築年区分との関連では，「2013 年 以降」を基準カテゴリとした場合に，「分からない」のカテ ゴリにおいて有意な負の関連が見られた。このことからは， 自身の住んでいる家の建築年を把握していない人は,「2013 年以降」の住宅に住んでいる人よりもヒートショックの健康 への影響を認識している割合が低いことが示されたといえ る。熱中症の場合と同様に, 他の建築年では有意な関連が ないことを踏まえると，建築年を把握していない人は，建築 年にかかわらず把握している人よりもヒートショックの健康へ の影響を認識している割合が低い可能性が示されたといえ る䀧 2)。両者の関連がなぜ見られるのかについては，因果 の方向などを含め更なる検証が必要であり，「分からない」 と回答しやすい傾向による見かけ上の関連の可能性もあるも のの，住宅に関する正しい情報を得ることができるような環 境や仕組みづくりが, 生活者にとって, 単に住環境を知る機 会を提供するにとどまらず，個々人の健康に対する意識促進

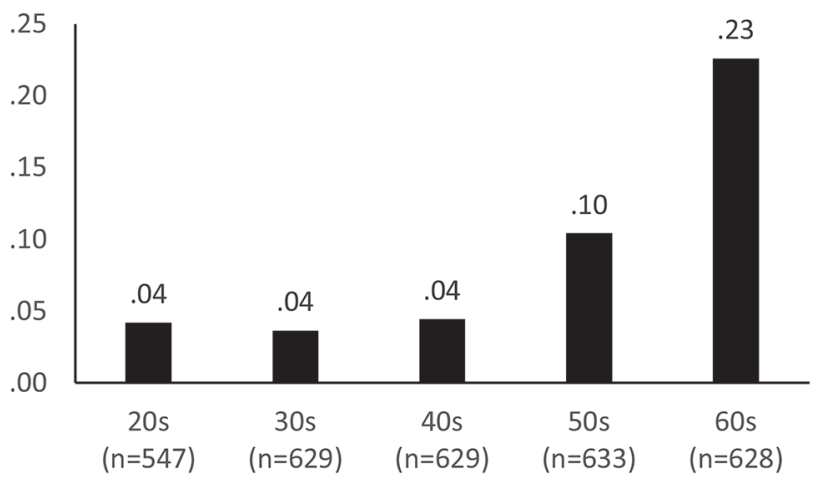

Fig. 1 Proportion of people measuring daily blood pressure in each age

脚注 2) 後述の通り, Table 5 の建築年区分で最もオッズ比が小 さかった「1992〜1998 年」を基準カテゴリとしてロジス ティック回帰分析を行った場合でも「分からない」のカテ ゴリで有意な負の関連が見られており,この可能性を支 持する結果となった。
や病気の予防に貢献できる可能性についても考えることがで きる。また, 住宅の建築年区分ごとのオッズ比を確認すると, 「1999～ 2012 年」及び「1992〜 1998 年」ではオッズ比が 1 未満（それぞれ.98 と.76），「1980～1991年」及び「1979 年以前」では 1 よりも大きかった(それぞれ 1.28 と 1.49)。オッ ズ比の最も小さかった「1992〜 1998 年」を基準カテゴリと して改めてロジスティック回帰分析を行うと，「1980～1991 年」「1979 年以前」で有意な正の関連 $(p<.01$, オッズ比は それぞれ 1.68 と 1.94),「分からない」で有意な負の関連 $(p$ <.05, オッズ比は.69）が見られた。こちらも熱中症の場合 と同様に, 古い建物の方が, 断熱性能が相対的に低く, 外 気温の影響を強く受けやすいため，たとえ長い時間とどまる 居室は暖かくしていたとしても，廊下やトイレ，浴室等につい ては寒さを感じやすく, 温度差を実感しやすいのではないか と考えられる。また, 古い建物の場合, 後述のように浴室暖 房等の設備の設置率が低いことから, 温度差を解消する手 段がそしく, 温度差を実感しやすくなっている可能性がある。

健康への態度・行動との関連では, 「食事志向 (F1)」で 有意な正の関連が見られた。オッズ比を確認すると, 熱中症 の場合の関連よりもやや小さいものの, 日々の生活の中での 健康への配慮という点に扔いて, 熱中症の場合と同様にヒー トショックの健康リスクの認識との間にも何らかの共通要因 がある可能性が考えられる。

冷暖房への態度・行動との関連では,「冷暖房忌避 $(\mathrm{F} 1) 」$ 「暖房積極利用 (F2)」では有意な関連は見られず，「冷房積 極利用(F3)」においてのみ有意な正の関連が見られた。ヒー トショック対策においては, 暖房が重要であるにもかかわら ず，「暖房積極利用（F2）」では関連が見られず，「冷房積極 利用 (F3)」で正の関連が見られたという点については, 直 感に反する結果だといえる。オッズ比の值からは，相対的に 大きな関連ではないと考えられるものの，今回の結果のみで は十分な検討を行うことは難しく, 今後のより詳細な検証が 求められる。

省エネ行動との関連では, 冷暖房に関する省エネ行動, その他の省エネ行動のどちらも有意な正の関連が見られた。 オッズ比は, 冷暖房に関する省エネ行動で 1.34 , その他の 省エネ行動では 1.53 であり, 熱中症の健康への影響の認識 有無の場合と比べて，相対的に小さな関連であった。この 結果からは, 熱中症の場合ほどではないものの, 省エネ行 動をとっている人の方が, ヒートショックの健康への影響に ついてより認識していることが示された。これらの関連につ いても, 熱中症の健康への影響の認識との関連と同様に, 生活における心理的・時間的な余裕や省エネ行動への行動 評価などを念頭に置きながら, 設問の見直しや追加等を含め てより詳細に検討していくことが必要である。

\subsection{4 ヒートショックの対策実施の有無との関連について}

熱中症の健康への影響について認識している人を対象と して $(n=2447)$, 対策実施の有無との関連について見ると, 高齢者（65歳以上）との同居において有意な正の関連が見 られた。回答者自身の年代では関連が見られず，高齢者と 
の同居において関連が見られたという点は，健康への影響 の認識有無とは異なっている。一つの可能性としては, 健康 への影響については, 自身の状況や経験を通じて認識する のに対して，実際の対策実施の有無においては，自分自身 のためというよりも, 同居している他者 (多くの場合, 家族 の誰かであろう）のための方が行動化しやすいということが 考えられる。この他者のための方が行動化しやすいという点 については，利他的な行動という見方ができる一方で，「他 者への配慮」をエネルギー消費のための理由として用いてい るという見方もできる（近い概念としては, “環境や社会, 人 のため”の消費であるとする「エシカル消費」や, 正当化で きる理由をつけることで消費行動に対する抵抗感を減らす, いわゆる「言い訳消費」などが挙げられるだろう)。いずれ にしても, 配慮すべき他者の存在がヒートショック対策を促 進する可能性があるという点について, 今後のさらなる検討 が必要である。

省エネルギー施策に基づいた住宅の建築年区分との関連 では，「2013 年以降」を基準カテゴリとした場合，投入した 全てのカテゴリとの間に有意な負の関連が見られた。直近の 建築年区分と比較して全ての建築年において負の関連が見 られた背景には，新しい住宅に拈けるヒートショックの対策 のしやすさを指摘できる。ヒートショックの対策方法は, 急 激な気温の変化を防ぐことであるが, 新しい建物の場合, 断 熱性能の高さによって屋内の場所間の温度差がそもそも小さ いというだけでなく, 保温便座や浴室暖房, 廊下の床暖房, 洗面所のヒーターといった, 具体的な対策をしやすい設備が 整っている場合が多いのではないだろうか。本研究で用いた TOKYO LIFESTYLE 調査の別項目では, 保温便座及び浴 室暖房に関して, 保有の有無について聴取している。住宅の 建築年区分ごとの保温便座, 浴室暖房それぞれの保有率を 見ると, 住宅の建築年区分が新しいほど保有率が高いこと が示された（Fig. 2 参照。カイ二乗検定では，住宅の建築 年区分による保温便座, 浴室暖房それぞれの保有率の違い はどちらも $p<.001$ で有意)。対策をしやすい住環境である ことが, ヒートショック対策の実践を促進させている可能性 が考えられる。

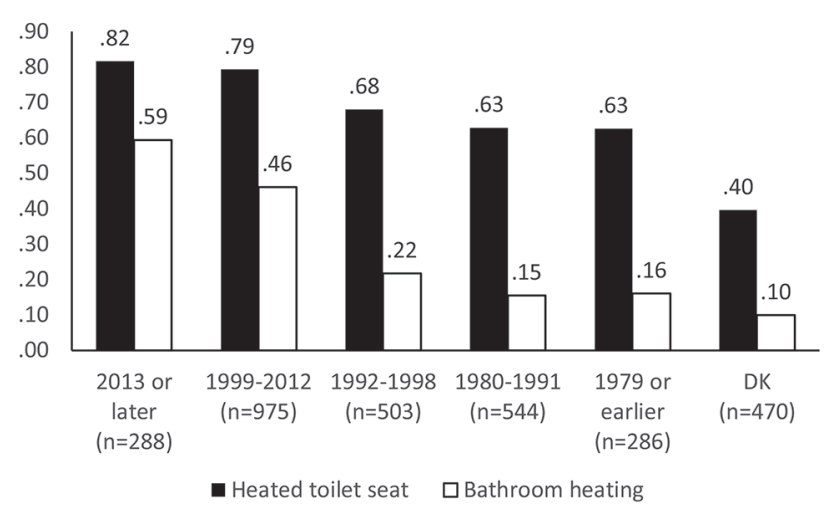

Fig. 2 Installation rate of heated toilet seat and bathroom heating in each house construction year

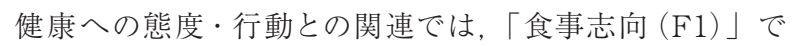

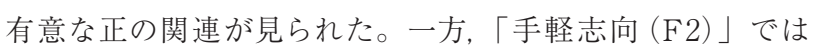
有意な関連は見られなかった (ただし, $p<.10$ で有意な傾 向が示された)。この結果からは,「食事志向 (F1)」が高い 人は, 熱中症の対策実施の有無と同様に, ヒートショックに おいても対策を実施しやすいと考えられる一方で,「手軽志向 (F2)」については, 熱中症の対策実施の有無で見られたよ うな関連がない，またはごく小さいと考えられる。これまで にも述べたように，本研究の分析データでは，どのような対 策を行っているのかについて具体的な内容を聴取できていな い。今後は, 熱中症及びヒートショック対策の具体的な実施 内容や取り組みやすさなどの情報に関しても収集し, それが 健康に対するアプローチとどのように関連しているのかにつ いて検討していくことが，対策実施の促進を考えていく上で 重要になると考えられる。

ヒートショックの対策実施の有無と冷暖房への態度・行動 との間には, 有意な関連が見られず，また，省エネ行動に関 しては, 冷暖房以外の省エネ行動に関してのみ有意な正の 関連が見られた。これは, 熱中症の対策実施の有無におけ る関連の仕方とは大きく異なっていた。この関連の差異につ いては, 熱中症とヒートショックそれぞれの特性や対策の違 いによってもたらされた可能性について考えることができる。

熱中症は, 個人の健康状態を含め様々な要因はあるもの の, 一般的に気温・室温や湿度の高い場所に長時間とどま ることによって生じる。そのため, 室内における冷房機器に よる対策としては，基本的に長い時間とどまる居室（居間， 寝室, 台所等) において講じられることが多いと考えられる。 一方で, ヒートショックは, 寒暖差による血圧の急激な上昇 または下降によって引き起こされる。そのため, 暖房機器に よる対策としては，長い時間とどまる居室と，長い時間はと どまらないものの必要に応じて利用するトイレ, 洗面所, 浴 室といった居室以外の温度差を無くすことが求められ, 居室 以外をどうやって暖めるかが問題となる。そして, 居室以外 をどのように暖めるかについては, 全館空調のような場合を 除くと，各場所に何らかの暖房機器を設置する，あるいは， ドアを開け放つなどして居室の暖かい空気を他の場所に送 るといった手段が講じられることとなる。居室に暖房設備が 一切ない住宅はそれほど多くないと予想される一方で, 居室 以外に十分な暖房設備がある住宅は, 前述のような建築年 の新しい住居でなければ, それほど多くないと考えられ, 結 果として, 暖房機器に頼るヒートショック対策には限界があ るのではないかといえる。そのため, 例えば居室外の場所に 行く際には一枚着込んでいく, スリッパや靴下をはく, そも そもできるだけ居室の外に出ない(比較的温度の高い昼間の うちに用事を済ませる)， あるいは入浴の場合はあらかじめ シャワーを出しておくなどして浴室温度を高くするといった暖 房機器以外の対策が有効かつ現実的な手段として実践され やすくなるのではないだろうか。このように考えると，ヒート ショック対策として暖房を積極的に利用したいと考えていて も, 居室以外では利用しにくいという制約があるために, ヒー 
トショック対策と冷暖房への態度・行動との関連は相対的に 小さくなる可能性が考えられる。

冷暖房に関する省エネ行動では関連が見られなかった点 についても同様のことがいえる。Table 1 に示したように，冷 暖房に関する省エネ行動の中には，「暖房する部屋の数を 減らす」「暖房する時間や期間を減らす」「複数の部屋で冷 房を使わないよう，できる限り一箇所に家族が集まって過ご す」のように，省エネとして，冷暖房を使う場所や時間を制 限する行動が含まれている。先に述べたように，熱中症の場 合，長い時間を過ごすメインの居室で冷房を利用することが 対策につながる一方で, ヒートショックの場合は, 居室以外 との温度差を無くすことが対策の目的となる。そのため, 暖 房を利用する場合には，メインの居室以外の多くの場所で使 うことが求められる。これは, 冷暖房に関する省エネ行動と は両立しにくい行動だと考えられる。このことを踏まえると, 熱中症の健康への影響の認識及び対策実施の有無と省エネ 行動との関連の際に考察したように，省エネ行動と対策の実 施との間には生活に対する心理的あるいは時間的な余裕と いった何らかの共通要因があり，それによって正の関連が生 じている一方で, ヒートショックの対策の場合，冷暖房に関 する省エネ行動そのものとの間にはむしろ負の関連があり， 互いの関連が相殺されてしまっている可能性がある。繰り返 しとなるが，より詳細に検討するためには，取組の実施有無 だけでなく，具体的な取組内容まで聴取した上で，冷暖房 に関する省エネ行動との関連について検討していくことが求 められる。

\section{2 .7 総合考察及び今後の課題}

本研究では, 熱中症及びヒートショックの健康への影響の 認識の有無及び対策実施の有無と, 個人属性や住宅の建築 年, 健康及び冷暖房への態度・行動, 省エネ行動との関連 について検討を行った。

熱中症の健康への影響の認識の有無については, 住宅の 建築年や健康及び冷暖房への態度・行動, 省エネ行動につ いてそれぞれ関連が見られた。熱中症の対策実施の有無と の関連では, 性別, 金融資産, 健康及び冷暖房への態度 行動, 省エネ行動で関連が見られた。ヒートショックの健康 への影響の認識の有無については, 個人属性のうち性別と 年代との関連が見られ，また，住宅の建築年や健康及び冷 暖房への態度・行動, 省エネ行動についてもそれぞれ関連 が見られた。ヒートショックの対策実施の有無では, 高齢者 （65 歳以上）との同居有無, 住宅の建築年や健康への態度. 行動, 冷暖房以外の省エネ行動との間に関連が見られた。

これらの結果を踏まえると, 熱中症及びヒートショックの 健康への影響の認識及び対策実施の有無には, 性別や年代 といった個人属性，高齢者との同居や住宅の建築年をはじ めとしたその人を取り巻く住環境に加えて, 健康や冷暖房に 対する意識や行動実践, 省エネ行動といった様々な要因が 関連している可能性が示唆されたといえる。また，仮説とし て, 生活に対する心理的あるいは時間的な余裕が, 熱中症 及びヒートショックの健康への影響の認識及び対策実施の
促進に寄与する可能性が示された。

さらに，熱中症とヒートショックでは，それぞれの対策に おいて冷暖房の活用の仕方が異なっており, それが両者の関 連の仕方の違いに表れている可能性が示された。熱中症の 対策では, ヒートショックの対策と比較して冷暖房の利用に 対する態度や行動が相対的に大きな関連を持つと考えられ, 冷暖房に関する省エネ行動が熱中症の対策実践とは相反し ない可能性が示された。他方, ヒートショックの対策では, 住居の温熱環境が重要であるという点においては熱中症と 同様であるものの, 居室の温度管理が重視される熱中症対 策とは異なり, 居室以外の温度管理が重要であり, それが 冷暖房に対する意識や行動, あるいは冷暖房に関する省エ ネ行動との関連を小さなものとしている可能性が示された。

一方, 本研究で分析デー夕は, 本研究の目的の元に聴取 されたものではなく，定期的に実施されている調査結果の データを用いた二次分析であった。そのため，標準化された 尺度を用いたものではなく，また，聴取項目についても，対 策の具体的な内容を聴取していないなど, 十分な考察がで きたとはいえなかった。また, Nagelkerkeの $R^{2}$ やオッズ比を 見ると, 今回示された関連は全体的にそれほど大きなものと はいえないことから, 一連の結果の解釈と一般化可能性につ いては慎重を期すべきであろう。これらのことを踏まえると, 本研究の位置づけとしては, 今後のより詳細な検証に向けた 仮説探索のための資料, あるいは, より正確なデー夕収集 に向けた端緒としての研究ととらえるべきである。

最後に, 上記を踏まえ, 本研究の限界と今後の課題につ いて整理する。一点目は, 項目の洗練が十分でなかった点 が挙げられる。前述の通り, ロジスティック回帰分析の結果 の個々の変数におけるオッズ比は, 全体的にそれほど高いも のとはいえなかった。この結果については, 想定した構成概 念や行動間の関連が本当に低かったのか，あるいは，測定 に用いた項目の妥当性や信頼性の低さが関連の希薄化を招 いているのかについては区別することができない。関連につ いてより明確に検討するためには，測定に用いる項目につい て, 標準化されている既存の尺度の利用や, 目的に合わせ た尺度の作成を行うなど，より厳密な手続きを用いる必要が ある。例えば, 健康への態度·行動に関連した尺度としては, Breslowの健康習慣に関する7 項目があるが 13)，それには， 食事や運動以外に, 睡眠や喫煙, アルコール等に関する項 目も含まれている。冷暖房への態度・行動についても, 具体 的な機器の種類や設置場所, 使用頻度なども含め, より詳 細な情報について聴取する必要があるだろう。さらに, 今回, 熱中症及びヒートショックの対策についての具体的な内容に ついて聴取できていないことは，詳細な考察を妨げる大きな 要因となった。本研究に用いたデー夕は定期的に実施してい る調査の結果であったため, 必ずしも目的に合致した項目を 網羅的に聴取できていたとはいえなかった。今後, 研究をよ り発展させていくためには, 既存の調査の中で利用できる項 目を用いつつ, 研究の枠組みに沿った調査設計とデー夕収集. 分析を丁寧に行っていく必要がある。 
二点目は, 本研究が一時点の横断データを用いた分析で あった点が挙げられる。そのため, 影響, 被影響の関連に ついての検討ができなかった。観察研究の場合, 厳密な因 果関係を明らかにすることは難しいものの, 時系列の情報な どを用いることによって, 因果推定の確からしさを向上させ ることは可能である。今後, パネルデータを用いて, 時系列 を組み込んだ分析や，個人間の差を調整する等，より関連を 明確にできるような形による研究計画の立案と検証が求めら れる。

三点目としては, 本研究及び今後の研究で得られる知見 を活かしながら, 発展的な形で実際の施策について考えてい く必要性が挙げられる。生活者の健康や冷暖房に対する肯 定的な態度・行動が熱中症やヒートショックの健康への影響 の認知促進や対策の実施促進につながる可能性がある, あ るいは, そうした態度や行動以前の, 築年数や冷暖房設備 といった住環境, さらには, 高齢者のように配慮すべき他者 の存在や生活に対する心理的あるいは時間的な余裕といっ た要因が影響する可能性があるのであれば, それらのメカニ ズムやプロセスを検証していくだけでなく, 実際の行動促進 につなげていくことは社会的に大きな意義がある。近年, 行 動経済学の分野では「ナッジ」の概念が改めて注目されてお り，一般生活者のターゲット行動の促進につなげようという 実践的な取組も多くなっているが, そうした分野の方法論や 知見なども生かしながら，より具体的な取組につなげていく ことが求められる。

\section{4. 結 言}

本研究の結果からは, 健康への態度・行動や冷暖房への 態度・行動, 省エネ行動が熱中症やヒートショックの健康へ の影響の認識や対策実施の有無と関連することが示された。 また, それ以外の住宅の建築年などの要因も関連する可能 性が示唆された。一方で, 利用できるデータの限界によって, その検討は十分なものとはいえず, 今後, 本研究を端緒とし てより詳細な検討を行っていくことが求められる。

熱中症, ヒートショックともに日々の生活における重大な 健康リスクである。今後は, 本研究で得られた知見を利用し つつ, デー夕収集のための項目や方法の洗練や, 実際の対 策促進のための実践的な検証等について, より長期的な視 点から研究を発展させていかなければならない。

\section{文 献: References}

1) Ministry of Health, Labour and Welfare, https://www. mhlw.go.jp/toukei/saikin/hw/jinkou/geppo/m2018/09. html (Last access: 2019.2.14) : 厚生労働省, https://www. mhlw.go.jp/toukei/saikin/hw/jinkou/geppo/m2018/09. html (Last access: 2019.2.14)

2) Tokyo Metropolitan Institute of Gerontology, https:// www.tmghig.jp/research/release/cms_upload/press_ 20131202.pdf (Last access: 2019.2.14) : 東京都健康長寿 医療センター研究所, https://www.tmghig.jp/research/ release/cms_upload/press_20131202.pdf (Last access: 2019.2.14)

3) Ministry of Health, Labour and Welfare, https://www. mhlw.go.jp/file/06-Seisakujouhou-10900000-Kenkoukyoku/ necchusho25_1.pdf (Last access: 2019.2.14) : 厚生労働省, https://www.mhlw.go.jp/file/06-Seisakujouhou-10900000Kenkoukyoku/necchusho25_1.pdf (Last access: 2019.2.14)

4) Shibata, Y.; Tobita, K.; Matsubara, M.; Kurazumi, Y., Jpn. J. Biometeor, 47(2), 119-129 (2010) : 柴田祥江, 飛田 国人, 松原斎樹, 藏澄美仁, Jpn. J. Biometeor, 47(2), 119129 (2010)

5) Ministry of Land, Infrastructure, Transport and Tourism, http://www.mlit.go.jp/report/press/house07_hh_000164. html (Last access: 2018.6.4) : 国土交通省, http://www. mlit.go.jp/report/press/house07_hh_000164.html (Last access: 2018.6.4)

6) DAIKIN, http://www.daikinaircon.com/cocotas/ heatshock.html (Last access: 2018.6.4) : ダイキン, http:// www.daikinaircon.com/cocotas/heatshock.html (Last access: 2018.6.4)

7) Miyake, Y.; Aruga, T.; Inoue, K.; Okudera, H.; Kitahara, T.; Shimazaki, S.; Tsuruta, R.; Yokota, H., JJAAM, 21, 230-244 (2010) :三宅康史, 有賀徹, 井上健一郎, 奥寺敬, 北原孝雄, 島崎修次, JJAAM, 21, 230-244 (2010)

8) Sawashima, T., J. Fac. Edu. Saga Univ., 2(2), 37-46 (2018): 澤島智明, J. Fac. Edu. Saga Univ., 2(2), 37-46 (2018)

9) Ministry of Land, Infrastructure, Transport and Tourism, https://www.mlit.go.jp/common/001082964.pdf (Last access: 2019.6.24): 国土交通省, https://www.mlit. go.jp/common/001082964.pdf (Last access: 2019.6.24)

10) Hirose, Y., Japanese Journal of Social Psychology, 10(1), 44-55 (1994):広瀬幸雄, 社会心理学研究,10(1), 44-55 (1994)

11) Ministry of Health, Labour and Welfare, https:// www.mhlw.go.jp/file/04-Houdouhappyou-10901000Kenkoukyoku-Soumuka/nettyuu_leaflet26.pdf (Last access: 2019.6.27) : 厚生労働省, https://www.mhlw.go.jp/ file/04-Houdouhappyou-10901000-Kenkoukyoku-Soumuka/ nettyuu_leaflet26.pdf (Last access: 2019.6.27)

12) Japan Preventive Association of Life-style related Disease, http://www.seikatsusyukanbyo.com/ statistics/2016/009091.php (Last access: 2019.6.27) : 一般社団法人日本生活習慣病予防協会, http://www. seikatsusyukanbyo.com/statistics/2016/009091.php (Last access: 2019.6.27)

13) Breslow, L.; Enstrom, J. E., Prevent Med, 9(4), 469-483 (1980) 